\title{
STUDIES ON CHELONUS SP. THE PARASITE OF THE COCONUT MOTH BATRACHEDRA ARENOSELLA WALKER
}

\author{
By \\ Wily A. Baringbing and Bariyah Baringbing ${ }^{1}$
}

\begin{abstract}
An experiment was conducted at a coconut pest laboratory at Nita, elevation $250 \mathrm{~m}$, Sikka regency, Flores island, province of East Nusa Tenggara, to study mass production of Chelonus parasite by using Phthorimaea operculella Zeller as its host, in an effort to control the coconut moth, Batrachedra arenosella Walker, biologically. Results of the experiment showed that the parasite could be produced in laboratory by using P. operculella as the host and a $10 \%$ solution of honey as food for both parasite and the adult host. A female parasite gave an average of 14 offspning during their lives with a sex ratio of $2.27: 1$, between male and female. The sex ratio of the same parasite in the field with B. arenosella as its host was 1:1. The incubation period of the parasite in laboratory was 26 days for males and 27 days for females. The sex ratio of the moth in the field as 1: 1.26.
\end{abstract}

\section{INTRODUCTION}

The coconut moth, Batrachedra arenosella Walker (Lepidoptera: Cosmopterygidae), is one of the serious pests of coconut palm, Cocos nucifera Linnaeus, in Indonesia (Tjoa, 1953; Kalshoven, 1981; Lever, 1969). Three promices, East Nusa Tenggara, West Nusa Tenggara and Central Sulawesi are the most infested areal more Lhan 25,000 ha. have long been heavily infested and the insect is regarded as the fifth serious pest of coconut in Indonesia (Samino, 1981).

Many attempts have been made to reduce the population density of the pest such as by mechanical, biological and chemical methods of control (Kasumbogo, 1973; Baringbing and Bariyah, 1977). In Lhe mecharnical method, the open spathe (spathe 0), the spathe about to open (spathe-1), and the next smaller spathe (spathe-2) were cut, collected and bwmed. The biological method of control was formed by releasing Lhe pupae parasite Chelonus sp. (Hymenoptera: Braconidae), the mechanical method by putting contact insecticides on spathe-3 (smaller than spathe-2). Spathe 0, -1 and -2 in the chemical control method were also collected and bumed. Buming of these spathes are necessary before carrying out the insecticide treatment to prevent the release of the pest from infested spathes.

The present experiment in Flores island in the province of East Nusatenggara, Indonesia, was conducted in an effort to control the moth biologically, using Chelonus as a parasite. Mass production of the parasite was attempted using Athotimaea operculela Zeller as a pest of potato tuber as its host, since the target moth, B. arenosella, cannot be reared in laboratory (Baringbing, 1982). The experiment was conducted at the village of Nita, elevation 250 m. In 1950, a Dutch scientist, Dr. Vos, has also introduced the parasite to the island but gave no scientific report of her experiment.

${ }^{1}$ Coconut Research Sub Institute, Pakuwon, West Java and Coconut Research Institute for Spices and Medicinal Crops, Bogor, West Java. 


\section{MATERIALS AND METHOD}

\section{A. MASS PRODUCTION OF THE PARASITE}

Three steps should be taken to produce the parasite in the laboratory. They are:

\section{Collection of the Moth B. Arenosella}

Spathes of coconut palms - 1 are cut from an infested area and are opened carefully in the laboratory. The pest, especially in the pupal stage, is put into 1 litre plastic container. Adult parasites will come out from the mfected pupae.

\section{Rearing of the Host, P. Arenosella}

Adult P. operculella arc collected from potato fields and arc placed in plastic containers with cotton wool soaked in $10 \%$ honey as a source of food. Eggs are laid on the under surface of the cotton fabric used to close the container.

\section{Rearing of the Parasite, Chelonus sp.}

Parasites emerging from pest pupae mi step 1 are placed in test tube in pairs to ensure mating. The gravid females are then taken to new plastic containers of 21 capacity where they are also provided with cotton wool soaked in $10 \%$ honey. Lids of containers from step 2 (with eggs of P. operculella) are transferred to the container with Chelonus females so that the P. Operculella eggs may be parasitised.

Two days later, the cotton fabric of the lid, now containing parasitised eggs is removed and wrapped around potato tubers, Solanum tuberosum, which are then placed in an empty container. The tuber provides a food source for the parasitised and non-parasitised larvae of P. operculella which einerge from these eggs. When the larvae have entered the potato tuber, after about 6 days, the cotton fabn'c is opened out. Adults of both P. operculella (from uninfected eggs) and of Chelonus emerge from pupae after about 4 weeks.

\section{B. INFECTION OF THE EGGS}

To study the infection, incubation period and the sex ratio of Chelonus in the body of P. operculella, 5 pairs of parasites were put in each of 12 containers of 21 capacity and closed with cotton fabric. Five female parasites, which had just mated, and 200 eggs of the host to be infected, were put into each plastic container.

\section{TO STUDY THE SEX RATIO OF B. ARENOSELLA AND CHELONUS IN THE FIELD.}

To study the sex ratio of the moth and the parasite in the field, 100 mature coconut trees, selected at random, were observed. One spathe - 1 from each tree was taken and the pupac obtained were reared in laboratory. The number of male and female of both B. arenosella and Chelonus were counted to see sex ratio.

\section{RESULTS AND DISCUSSIONS}

Chelonus parasite could be produced by mass rearing in the laboratory by using P. operculella as the host. The mean number of offspring of each female parasite in the laboratory was 14 (Table 1) with a sex ratio, between males and females of 2.271 (Table 2). The mean incubation period of the parasite was 26 days for males and 27 days for females in the body of $P$. operculella 
(Table 1). The sex ratio of the same parasite in the field, with B. arenosella as the host was $1: 1$ (Table 3). The sex ratio of the pest in the field was 1:1.26 (Table 2). A 10\% solution of honey was switable food for both adult and parasite and adult P. operculella.

A sex ratio of approximately 1: 1 is desirable of parasites reared in the laboratory to be used in the biological control of B. arenosella. The observations suggest that a high ratio of males to females in the laboratory is a result of inadequate fertilization.

One important considerationuii rearing the parasite is that the mating should occur as soon as the adult braconids come out from the pupal host because their mating ability decreases thereafter. It is also possible that the parasites in the test tube do not mate. Thus, one or two or more parasites should be added into the test tube to increase the chance of successful mating.

Field trials with laboratory-reared Chelonus are now in progress.

Table 1. Infection, incubation period and the sex ratio of ChelonusParasite in the laboratory with P. operculella as its host

\begin{tabular}{|l|r|r|r|r|}
\hline \multicolumn{1}{|c|}{$\begin{array}{c}\text { Parasite Parent } \\
\text { (in pair) }\end{array}$} & \multicolumn{2}{c|}{ Offspring } & \multicolumn{2}{c|}{ Mean incubation period (day) } \\
\hline & \multicolumn{1}{|c|}{$\delta^{*}$} & \multicolumn{1}{c|}{$+\sigma^{*}$} & \multicolumn{1}{c|}{} \\
\hline 60 & 578 & 2.54 & 104.80 & \\
\hline Mean 1 & 9.63 & 4.23 & 26.17 & 109.08 \\
\hline Offspring & \multicolumn{2}{|c|}{13.86} & & 27.34 \\
\hline Sex ratio & 2.27 & 1 & & \\
\hline
\end{tabular}

Table 2: Observation of the sex ratio of $B$. arenosella in the field

\begin{tabular}{|l|c|c|c|}
\hline \multirow{2}{*}{$\begin{array}{c}\text { No of trees } \\
\text { observed }\end{array}$} & \multirow{2}{*}{$\begin{array}{c}\text { Total trees } \\
\text { Infected }\end{array}$} & \multicolumn{2}{|c|}{ No of adult moth } \\
\cline { 3 - 4 } & 89 & $\sigma^{\star}$ & q \\
\hline 100 & & 302 & 382 \\
\hline Sex ratio & & 1 & 1.26 \\
\hline
\end{tabular}

Table 3: Observation of the sex ratio of Chelonus in the field with $B$ arenosella as its host

\begin{tabular}{|l|c|c|c|c|}
\hline \multirow{2}{*}{$\begin{array}{c}\text { No of trees } \\
\text { observed }\end{array}$} & \multirow{2}{*}{$\begin{array}{c}\text { Infested area } \\
(\%)\end{array}$} & \multirow{2}{*}{$\begin{array}{c}\text { No of pupae of } \\
\text { The moth }\end{array}$} & \multicolumn{2}{|c|}{ No of parasite } \\
\cline { 4 - 5 } & & & $0^{*}$ & q \\
\hline 100 & 36 & 487 & observed & 47 \\
\hline Sex ratio & & & 1.02 & 1 \\
\hline
\end{tabular}




\section{ACKNOWLEDGMENTS}

I acknowledge the valuable technical assistance received from M/S Abdul Rojak, A.M. Theod, Alex L. Gaing, Gabriel Woda and Juliana. Iam also grateful to Dr. Peter Hunt for the great help given in preparing the manuscript.

\section{REFERENCES}

BARINGBING, W.A. 1982 Laporan perjalanan dinas ke Nusa Tenggara Timur. Balai Penelitian Tanaman Industry, Bogor, Unpublished.

BARINGBING, W.A. and Barlyah. 1977. Chemical and blological control of coconut pests in Indonesia. Seminar presented at Tamil Nadu Agricultural University, Coimbatore, India.

KALSHOVEN, L. G.E. 1981. Pests of Crops in Indonesia. Revised edition. P.T. Ichtiar Baru van Hoeve, Jakarta. 701 pp.

KASUMBOGO U. 1973. Evaluasi pemberantasan biologi terhadap hama kelapa Batrachedra di kabupaten Ngada. Laporan survey. Unpublished.

LEVER, RIA.W. 1969. Pests of coconut palm. FAO. Rome 190 pp. SAMINO, W. 1981. Pembinaan perlindungan tanaman perkebunan. Direktorat Jenderal Perkebunan, Jakarta, Unpublished.

TJOA, T.M. 1953. Memberantas hama-hama kelapa dan kopra. Noordhoff-Kolff, Djakarta. 270pp. 